\title{
Enlightenment of teacher education patterns in foreign countries on Chinese teacher education reform
}

\author{
Xiaoxia Zhang \\ Hebei North University, Zhangjiakou, 075000,China
}

\section{Keywords: Foreign teacher education; Patterns; Teacher education reform}

\begin{abstract}
It can be said that teachers are main force for educational reform. How to adapt to changing international environment and social environment has become a hot problem that all countries in the world pay much attention to. A number of countries consider teacher education in development prospect of their countries and nations and even all human beings in the future. Therefore, teacher education draws more and more attention. On the basis that foreign teacher educational pattern is analyzed, this thesis discusses enlightenment which teacher education patterns in foreign countries bring to Chinese teacher education reform.

Since the 1980s, overall quality of basic education in all countries of the world has declined and benefits have been low, which arouses all social sectors' worries and draws much attention from them. In order to improve educational quality practically, America begins to carry out reform of high quality education in order to improve educational quality and benefits. During this period, Britain changes the method nationally uniform course practically, which has never been used before, and improves all schools' teaching ability by national uniform standard in order to provide better education for students. At the same time, countries like France, Germany and Japan carry out comprehensive reform and put forward higher requirements for teacher education. In the quality-oriented education reform which is still being developed in China, teachers are an important factor that affects effectiveness of new curriculum reform undauntedly. Besides, improvement in overall quality of teachers depends on overall quality of teacher education in the country. Therefore, as new curriculum reform develops, teacher education reform draws more and more attention. For this, we should consult advanced experience in teacher education in foreign countries actively, which is quite helpful for improvement in teacher educational conditions.
\end{abstract}

\section{Analysis of foreign teacher educational patterns}

(I) Teacher education is featured by high level and high standard

Since the $20^{\text {th }}$ century, all countries in the world, especially developed countries, have devoted themselves to developing human resources and improving talent quality in order to improve their international competitiveness. Thus, they give priority to develop teacher education and treat it as an important objective and key point of educational reform and development. Some western developed countries compete with one another to improve level of teacher education and even cancel secondary normal education for this. In this aspect, America is a country with the most rapid progress and is the first one entering this. Currently, teachers at all middle schools and primary schools in America are mainly cultivated by education colleges of comprehensive universities. In recent years, America has canceled secondary normal education in reform and improved education background of primary and middle school teachers to master's degree and doctor's degree. Cultivation level of primary and middle school teachers is improved continuously. Since the first half of the $20^{\text {th }}$ century, France has carried out reform several times. Thus, term and length of schooling, when primary and middle school teachers in France accept educational training, are extended, and schools' specifications are upgraded continuously. Since the 1980s, France has treated teachers' cultivation and training as one of the important component of educational reform and extended primary and middle school teachers' length of schooling to 4 years, which is the same 
as the length o schooling of common universities. Japan locating in Asia has devoted itself to developing education after the Second World War and obtained remarkable achievements. Many universities cultivating primary and middle school teachers in Japan have established courses about master's degree. Besides, Tokyo Gakugei University, which is famous for cultivation of teachers, and other state-run universities jointly establish courses for doctoral students of graduate schools. Thus, convenience is provided for improvement in primary and middle school teachers' ability and quality.

\section{(II) Deepening curriculum reform and improving professional level of teachers}

Firstly, pay attention to integration of arts and science and strengthen construction of foundation courses. Teacher education in all countries values position and effect of foundation courses in its curriculum reform very much and tries to promote permeation between arts and science and combination of humanistic education and scientific education, hoping to improve teachers' professional level and let them adapt to new and higher requirements of technological development for teachers. Holmes Report issued by America in 1986 directly criticizes educational curriculum of teachers emphasizes positive implementation of curriculum reform currently after following old curriculum system in the middle period of the 19th century under the condition that science and technology is developed highly. In doing so, the report wishes to reform teacher education of the country and applies rich and systematic knowledge about arts and science and profound professional knowledge of subjects to enrich knowledge of teachers and students. New-type education universities of Japan establish courses like arts, science, physical education, artistic skills, industry and housekeeping and their trend is to develop towards large arts and large science. Realizing integration of housekeeping and social science by permeation of arts and science has become an inevitable development trend of foreign countries when they carry out teacher education. Secondly, value educational subjects and enhance practice of higher education. In order to improve teachers' professional level and teaching ability, teacher education courses of all countries pays much attention to theoretical teaching and practical teaching of the subject teacher education in the process in which they implement reform. Thus, educational theory courses and educational practice account for a large proportion in total class hours. At present, class hours of educational courses accounts for $20 \%$ of all class hours at normal colleges of America, ratio of educational courses to all courses of colleges of education at comprehensive universities that specially cultivate teachers in Japan reaches up to $15 \%$, and class hours of educational courses at normal universities in Britain accounts for $25 \%$ of all class hours. On the basis that class hours of educational courses is added, it is essential to extend the time of educational practice. Thirdly, expand content of professional courses of the subject and work hard to cultivate teachers' teaching quality. Western developed countries generally think that teachers should adapt to educational development and improve course teaching quality. Teachers should have comprehensive quality, i.e., they are good at many things and expert in one. Kent State University proposes the objective that it will cultivate teachers to be scholars, educators, contactors and even decision-makers in the process in which it implements reform of teacher education. With respect to design about professional courses, foreign teacher education and subjects established by China are corresponding and they mainly apply major and minor system. Japan lays much emphasis on construction of professional basic subjects. However, there is difference in professional basic subjects, i.e., required subjects and elective ones. Elective subjects account for a large proportion. Thus, credits of professional subjects occupy over $50 \%$ in total credits.

\section{(III) Realizing integration of teacher training and cultivation to strengthen continuing training of teachers}

Foreign teacher education is mainly divided into the following three types, i.e., oriented type, non-oriented type and synthesizing type, which can be called closed type, open type and mixed type as well. Considering the situation that educational business develops continuously and reform of teacher education in all countries deepens, western developed countries improves related system about teachers' cultivation and training successively. Most countries implement mixed-type training mode for teachers, include teachers' cultivation and training in integration pattern and relate 
pre-service cultivation to in-service training. Nowadays, pre-service education of all teachers and higher education in Europe pay more attention to cooperation and integration. Regardless of whether the change comes early or late, the common feature is that related institutions undertaking teacher education should relate pre-service cultivation to in-service training. Foreign countries value in-service training and cultivation of teachers largely so that they have placed key points of teacher education on in-service training and improvement and taken effective measures and policy to enable lifelong education and lifelong learning thoughts needed by the learning society to be carried out in teacher education. For instance, France specifies that primary school teachers much have 12 weeks' mid-career study every 6 years and teachers should accept lifelong training. Japan uses credits, degree and seniority which teachers get via further education as main basis on which they can get promotion and higher salary. Britain and America adopt direct salary increase to encourage teachers to take part in training and thus initiative and practical effectiveness of teachers' further education are improved.

\section{Enlightenment of teacher education patterns in foreign countries on reform of teacher education in China}

\section{(I) Adopting several forms to cultivate teachers actively}

Some practices in system reform of teacher education in Britain are worth consulting. Once situation development need teacher reform be reformed, Britain does not deny a kind of system simply. For example, it does not wish to cancel local normal colleges completely but carries out a brand-new system, i.e., all teachers are cultivated by comprehensive universities. Therefore, it is essential to start from our national conditions to form teacher education system with Chinese characteristics.

\section{(II) Promoting high-end orientation of teacher training}

According to development patterns of teacher education in foreign countries, teacher education develops towards a higher-level and professional direction gradually with demands of the society, which is helpful for improvement in teachers' quality. In the development process of China's teacher education, all primary and middle school teachers and kindergarten teachers should be cultivated by higher educational institutions. Otherwise, it will be impossible to satisfy modern people's requirements for teachers' teaching ability and education background. Thus, possession of higher education background must be one of the important conditions for teachers to take office at various kinds of schools in China. Primary school teachers in some western developed countries have bachelor's degree and requirements for teachers' education background are quite high. Teachers Law of China also specifies the qualification for primary school teachers is that they should graduate from secondary normal schools or have education background above this; junior middle school teachers should have college degree and above; senior middle school teachers should graduate from higher normal universities or other colleges or have education background above this. It should be noted that this requirement is the lowest requirement for Chinese teachers' education background. In consideration of continuous improvement in level of teacher education in China, requirements for teachers' quality increasingly rise. In the near future, new and higher requirements will be proposed for teachers' education background undoubtedly.

\section{(III) Improving reputation of teachers' job}

By investigating practical situations of teacher education and success and failure of basic education reform in foreign countries, it can be found that countries pay much attention to improving reputation of teachers' job as long as they are relatively developed countries and the ones where teachers' professional ability is splendid. For instance, Japan and Japan just have such a situation. Although China values teachers' specialization largely at present, position and treatment of teachers are not high enough. Hence, it is of important practical significance to improve reputation of teachers' job. To attract more excellent young people to choose teacher a sacred job, it is suggested that treatment of teachers should be improved and salary and social benefits of teachers should be equal to or a little higher than that of other employees with the same education 
background.

(IV) Improving enrollment threshold of normal schools

Originally, enrollment standard of normal universities and colleges in America is lower than that of comprehensive ones. Since the 1980s, America has guarded a pass of enrollment for normal students strictly and the standard for such students has been the same as other professional standards of comprehensive universities. Thus, the author suggests that China should improve enrollment standard of normal college students as much as possible. On the basis that graduates of senior middle schools take part in national college entrance examination, it is necessary to verify aptitude of students who apply for normal majors and choose excellent young people who really have professional development ability to accept teacher training. For example, six normal universities that are directly subordinate to Ministry of Education develop the policy that they recruit normal college students that do not need to pay tuition. This can improve teachers' degree of specialization at basic education schools in China inevitably.

(V) Constructing new-type system of teacher education

The country should encourage comprehensive universities and non-normal universities to take part in training of primary and middle school teachers and explore the practice that the country may try to run normal colleges at comprehensive universities with conditions actively. Nowadays, a batch of comprehensive key universities like Peking University and Zhejiang University has taken part in teacher training. Traditional closed-type teacher education system has been broken practically up to now, so we should consult experience of foreign countries in teacher education and let more students from non-normal universities can undertake job duties of primary and middle school teachers via training about teacher education in order to form an open mechanism for teacher education and training, where normal universities are subjects and other universities participate jointly. This is one of the important tasks we must discuss deeply at present. Meanwhile, China should take effective measures actively and work hard to realize the situation that center of teacher education system moves upward continuously so as to realize transition of teacher education from the third-level system to the second-level system and then to the first-level system as soon as possible and achieve the change from a closed-type teacher education pattern to an open one finally.

(VI) Forming system of teacher education integration

Teacher education integration mainly means pre-service training of teachers is integrated with in-service training approaches to enable teacher education to develop comprehensive implementation of overall planning in a uniform educational institution successfully. Teacher education should form integrated operation system, which is a consistent trend of teacher education development in the whole world and important requirement of sustainable development of teacher education simultaneously. It is essential to construct integrated new-type teacher education system to improve primary and middle school teachers' quality and promote better development of teachers. For sustainable development of teacher education, construction of a brand-new integrated situation about teacher education not only accords with thoughts and strategies of sustainable development but also reflects thoughts about lifelong education more sufficiently. Teacher education of China usually need cover the road of teacher education integration directly. Facing with increasingly fierce international education competition, China should improve teachers' quality and thus promote teachers to cover the road of sustainable development.

\section{Conclusion}

To sum up, in accordance with current status of teacher education in China, teacher education has the problem that pre-service training and in-service training of teachers are separated from each other. Pre-service training of teachers is mainly undertaken by teacher education, while in-service training and further education are implemented by professional institutions, for example, continuation schools for teachers. This problem goes against sustainable development of teachers. Thus, China should consult foreign countries' advanced experience in teacher patterns, apply it, improve utilization rate of educational resources and expand service functions of higher normal education to enhance strength of educational research and promote educational reform of primary 
and middle schools.

\section{Reference:}

[1] Guo Tao. Enlightenment of operating mechanism about teacher education in foreign countries on China [J]. Journal of Xi'an University of Arts and Science (Social Science Edition), 2010(5).

[2] Xiang Hua. Operating mechanism about teacher education in foreign countries and its enlightenment [J]. Teaching and management, 2011(15).

[3] Wen Weibin. Reform of international teacher education and countermeasures of China [J]. Jiangsu Education Research, 2011(19).

[4] Huang Min. Research overview about professional development of teachers and educators in foreign countries [J]. Foreign Education Research, 2012(12).

[5] Ma Yifei. Outstanding orientation of international teacher education reform - taking training plans for outstanding teachers in Britain, America, Germany and Australia [J]. World Education Information, 2014(8). 